\title{
ORAL DISORDERS RISK PREDICTION IN MACROSOMIC NEWBORNS AND INFANTS USING THEIR HEIGHT-WEIGHT INDEX AT BIRTH
}

\author{
Garmash 0. \\ Department of therapeutic dentistry, Kharkiv National Medical University \\ https://doi.org/10.35339/ic.6.3.179-190
}

\begin{abstract}
The purpose of the study was to identify the risk factors and to assess the differences in the risk of hard tooth tissue and periodontal tissue diseases formation in macrosomic newborns or infants, depending on their weight-height index at birth, with the help of questionnaire survey. Objects and Methods. The study involved 151 newborns or infants (aged from one day up to 6 months) during the period of 2014-2019. Sixty-eight children born macrosomic comprised the Main Group (MG), and the children of the corresponding age with normal weight-height parameters at birth (83 children) were included into the Comparison Group (CG). The groups were equally represented by male and female participants. MG children were additionally subdivided into 4 subgroups based on the weight-height parametres of a newborn child, using the classification proposed by Kharkiv scholars. The survey was carried out using previously developed questionary, which included 70 questions, divided into 7 scales. Results and Conclusions. The hygienic state of the oral cavity of parents, the presence of concomitant pathology of parents, bad habits and the degree of locomotor activity before pregnancy, and during pregnancy, peculiarities of nutrition and medical therapy of parents influence practically identically on the formation of oral disorders in children born normomic or in children born macrosomic, regardless of their weight-height index at birth. Reliable differences between groups and subgroups were not detected.

The effect of the total paternal factor on the formation of oral disorders in individuals with macrosomia at birth, can be different from the effect of this factor in normosomic-at-birth persons, but this difference is related to the same phenomenon that we are studying - the fetal macrosomia, but the paternal one. The highest risk of the oral pathology formation have children whose parents were born macrosomic.

A person born macrosomic, on the average, has twice as many complaints about oral health compared to a person born normosomic.
\end{abstract}

Keywords: oral cavity pathology, newborn, fetal macrosomia, questionnaire.

\section{Introduction}

Intrauterine processes leads to fetal macrosomia formation (the body weight of a newborn child is more than or equal to $4,000 \mathrm{~g}$ [1]) and creates prerequisites for the onset of numerous systemic diseases and pathological conditions [2]. Children with macrosomia at birth have inherent propensity to metabolic syndrome, obesity, diabetes and many other diseases [3-5].

Corresponding Author:

Olga Garmash MD, PhD, Associate professor

of the Department of Therapeutic Dentistry

Department, Kharkiv National Medical University,

Ukraine. E-mail: o.v.garmash@gmail.com
Dental abnormalities in such children are manifested by high intensity of deciduous and permanent teeth caries and a high prevalence of mallocclusions [6-8]. Due to the variety of reasons associated with macrosomia formation, and significant spread of the weight-height index values in macrosomic newborns, children whose antropometric indices at birth were higher than normal, are not a homogeneous group. Our previous studies has proved that the weight-height index of a child at birth is a reliable "indicator" of severity of oral disorders forming later [9]. In our opinion, the oral health in macrosomic-at-birth children also depends on their intrauterine development (well-balanced growth and body 
weight gain, or intrauterine obesity, or relative insufficiency of body weight).

There can be another view to this situation: parents' pathology of hard tooth and periodontal tissues, malloclusions, state of oral hygiene, comorbidity, their social habits, locomotor activity before pregnancy and during it, or the nature of nutrition and medical therapy influences the poor state of oral health in children. The dependence of the carious process intensity in children on the condition of their parents' oral cavity can not be denied [10]. Mallocclusion, in most cases, is also hereditary [11]. Limited locomotor activity (hypodynamia) of parents or parents' smoking may affect the timing of teeth eruption in children [12].

We have developed the questionnaire [13] that allows predicting the degree of risk of oral pathology formation in newborns, due to their higher parameters at birth associated with all the above-mentioned factors. It also helps highlight the most significant factors in their parents.

\section{Purposes, subjects and methods:}

2.1. Purpose of the study was to identify risk factors and to assess the differences in the risk of hard tooth tissue and periodontal tissue diseases formation in newborns or infants born macrosomic, depending on their weight-height index at birth, with the help of questionnaire survey method.

\subsection{Subjects \& Methods}

The parents of 151 newborns or infants (aged from one day up to 6 months) were interviewed during the period of 2014-2019. Sixty-eight children born macrosomic comprised the Main Group (MG), and the children of the corresponding age with normal weight-height parameters at birth ( 83 children) were included into the Comparison Group (CG). The diagnoses were verified by the neonatology physicians of the Kharkiv Municipal Perinatal Centre. The groups were equally represented by male and female participants. MG children were additionally subdivided into 4 subgroups based on the weight-height parametres of a newborn child, using the classification proposed by Kharkiv scholars [14].

Thirty seven children were assigned to the subgroup I (SG-I). At birth they were tall and harmoniously developed (weight-height index of such children at birth was comparable to that in the CG). Subgroup II (SG-II) included 14 children who were tall with relatively lower body weight (weight-height index was significantly lower than in children with CG) at birth. Subgroup III (SGIII) consisted of 10 children who at birth were tall and had obesity (the weight-height index at birth was significantly higher than that of the $\mathrm{CG}$ ).
Subgroup IV (SG-IV) included 7 children, whose body length at birth matched the body length in the $C G$, and the weight-height index indicated an intrauterine obesity. The principle of research participants distribution into the subgroup was described in details earlier [15].

The survey was carried out using the original questionary [13], which included 70 questions, divided into 7 scales. Scale 1 refers to the identification of risk factors of hard tooth tissue and periodontal tissue pathology development according to their past history data and complaints of the child's parents. It is evaluated by the answers to questions $1-10$. Scale 2 is intended for the detection of anatomical and functional factors of malocclusion in the child's parents. It is evaluated by the answers to questions 11-20. Scale 3 refers to the identification of the hygienic state of the oral cavity of the child's parents. It is evaluated by the answers to questions 21-30. Scale 4 can identify factors of the family hereditary predisposition for a child's being macrosomic. It is evaluated by the answers to questions from 31 to 40 . Scale 5 is intended to identify the factors of concomitant parent's pathology. It is evaluated by the responses to questions from 41 to 50 . Scale 6 refers to the detection of the effects of the social habits and physical activity before and during pregnancy. It is evaluated by the answers to questions 51-60. Scale 7 is designed to identify the nutritional factors and drug therapy of the child's parents. Itis evaluated by the answers to questions $61-70$. The text of the questionnaire is given in abbreviated form (Fig. l).

The degree of risk of hard tooth tissue and periodontal tissue pathology formation is evaluated as follows: risk is absent -0 points; minimal risk from 1 to 10 points; moderate risk - from 11 to 20 points; significant risk - from 21 to 30 points; high risk - more than 30 points.

Test results of the MG and CG participants, after checking on the Pearson criterion for the correspondence of their distribution to the Gauss law, were compared with each other by means of parametric statistics (Student t-criterion). Due to the small number of participants in subgroups, the study of differences in scales between MG subgroups and $C G$ was conducted using nonparametric statistics (Mann-Whitney criterion). The differences were considered reliable if the probability of error $\mathrm{p}$ did not exceed 0.05 . Confidence intervals (CI) for the percentage of positive answers (points) to questions in groups and subgroups were calculated on the assumption of binomial distribution of a random variable with probability of error $p<0.05$ [16]. 
Information about a newborn or an infant:

Date of birth

blood group, Rh factor

gender place of birth

circumference body weight body length head

delivery chest circumference

vaginal delivery premature birth

delayed birth gestational age timely

delivery by a c-section:

based on the fetus condition physiological pathological

a $I$ min Apgar score planned operation based on the mother condition urgent surgery

Whether the child was put to the breast in the delivery room

Whether the child was taken to the intensive care unit or a newbom resuscitation unit (indicate the number of days) after delivery Whether the child is breastfed or not

Diagnosis (from the Neonatal Case Record, Child's Record or Hospital Shect)

Information about newborn's parents:

marital status mother's age

height / weight of mother father's age

height / weight of mother at birth blood group, Rh factor of the mother height / weight of father height / weight of father at birth blood group, Rh factor of the father

Information on previous pregnancies of the newbom's mother: the delivery number the pregnancy number time interval after the previous delivery.

Describe whether the course of previous pregnaney was complieated by any factors, namely, whether there was: toxicosis, anemia, gestational diabetes, small vein or polyhydramnios of amniotic fluid, preeclampsia, manifested by increased blood pressure, edema, the presence of protein in the urine; whether the mother had infectious diseases during pregnancy; whether she was in hospital for pregnancy maintenanee; whether there was a threat of miscarriage; whether there were complications during delivery?

If mother, father, siblings or other close relatives of the newbom had the weight of $4 \mathrm{~kg}$. or more at their birth, indicate who exactly

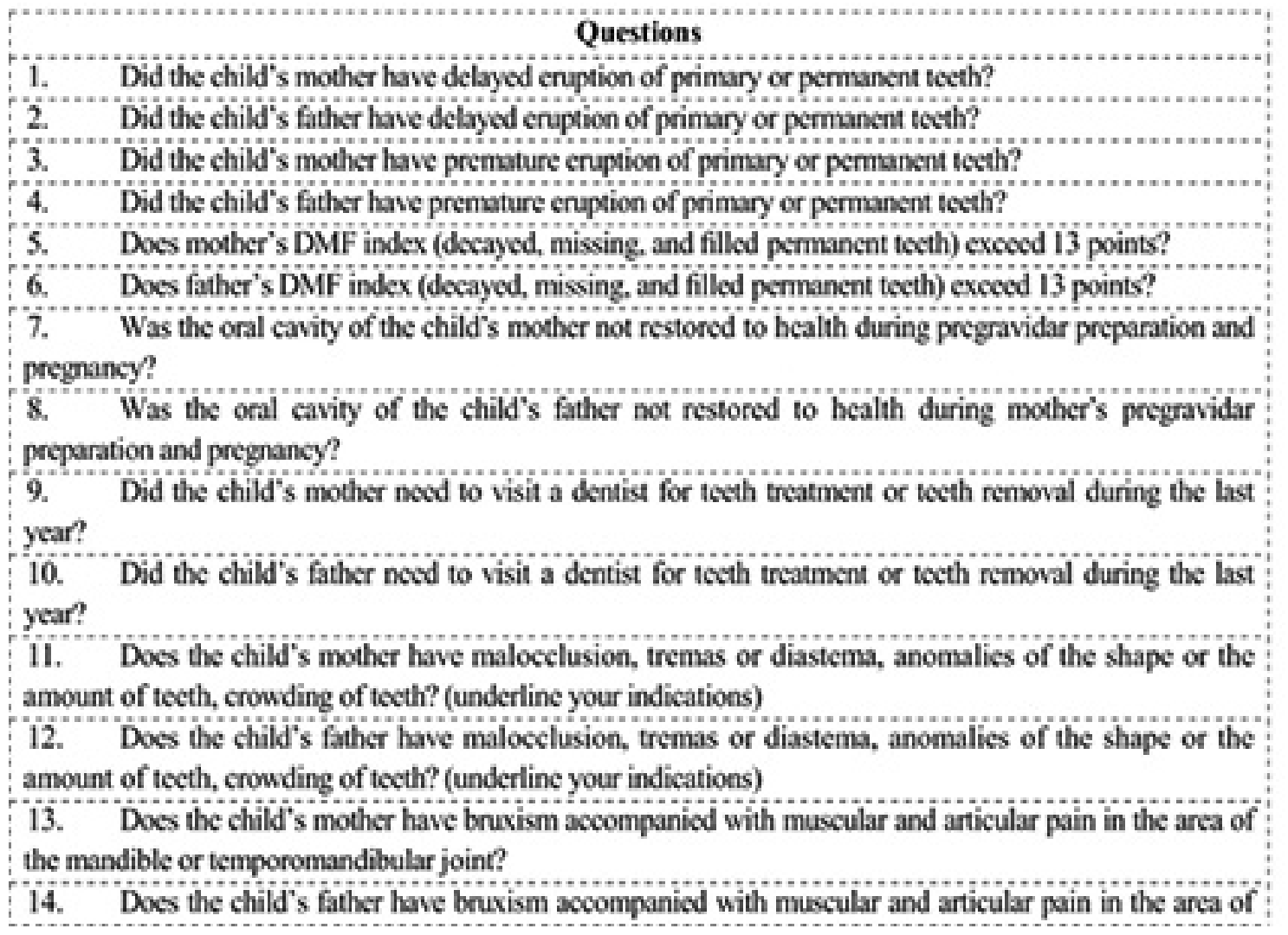


the mandible or temporomandibular joint?

is. Does the child $\mathrm{s}$ mother have periodontal diseases manifested as gingival bleeding while toothbrushing accompanied with mobile tecth and early tooth loss?

16. Does the child s father have periodontal diseases manifested as gingival blecding while toothbrushing accompanied with mobile tecth and early tooth loss?

17. 'Does the child's mother mark cninch in the temporomandibular joint, change in the motion of the mandible when opening or closing the mouth?

i8. 'Does the child's father mark crunch in the temporomandibular joint, change in the motion of the mandible when opening or closing the mouth?

i9. Does the child's mother or her close relatives have abnomal tooth abrasion?

20. Does the child's father or his close relatives have abnormal tooth abrasion?

21. Does the child's mother visit a dentist for preventive examinations, less often than once or twice a year?

22. Does the child 's father visit a dentist for preventive examinations, less often than once or twice a year?

23. Does the child's mother brush her teeth less often than twice a day?

24. Does the child 's father brush his teeth less often than twice a day?

25. Does the child s mother avoid changing her toothboush once every 34 months?

26. Does the child s father avoid changing his toothbush once every $3-4$ months?

27. Does the child's mother neglect special medications for prevention of periodontal and hard tooth tissue diseases such as remineralizing elixirs, balms, and rinses and additional hygiene tools such as floss, intradental brushes, massagers and others?

28. Does the child's father neglect special medications for prevention of periodontal and hard tooth tissue diseases such as remineralizing elixirs, balms, and rinses and additional hygiene tools such as floss, intradental brushes, massagers and others?

29. Does the child 's mother have dental braces or other removable and non-removable orthodontic or orthopedic appliances

30. Does the child's father have dental braces or other removable and non-removable orthodontic or orthopedic applianees?

31. Does the child's mother or her close relatives suffer an endocrine pathology, namely thyroid disease?

32. Does the child s father or his close nelatives suffer an endocrine pathology, namely thyroid disease?

33. Does the child's mother or her close relatives have diabetes?

34. Does the child 's father or his close nelatives have diabetes?

35. Does the child 's mother have obesity of ist stage or more at the moment, preciscly whether the mother's weight exceeds $20 \%$ of the physiological norm?

36. Does the child's father have obesity of Ist stage or more at the moment, precisely whether the father's weight exceeds $20 \%$ of the physiological norm?

37. Does the child s mother have following anthropometric characteristics height is abowe $170 \mathrm{~cm}$, weight is more than $80 \mathrm{~kg}$ ?

38. Does the child's father have following anthropometric characteristics beight is above $180 \mathrm{~cm}$. weight is more than $90 \mathrm{~kg}$ ?

39 . Is the child s mother older than 30 ?

40 . Is the child s father 40 or older?

41. Does the child's mother have atopic dermatitis, asthma, allergic ninitis and other allergic manifestations?

42. Does the child's father have atopic dermatitis, asthma, allergic rhinitis and other allergic manifestations?

43. 'Does the child's mother have hip dysplasia or dysplasia of other joints, common dislocation of the 
joints, stretch marks on the skin, flatulence, and abnormal chord of the left ventricle, mitral valve prolapse, or myopia? (underline your indications)

44. Does the child 's father have hip dysplasia or dysplasia of other joints, common dislocation of the joints, stretch marks on the skin, flatulence, and abnormal chord of the left ventricle, mitral valve prolapse, or myopia? (underline your indications)

45. Does the child's mother have brittle nails or dry skin, violation of the hair structure (hypotrichosis), poor growth and hair loss?

46. Does the child s father have brittle nails or dry skin, violation of the hair structure (hypotrichosis). poor growth and hair loss?

47. Does the child's mother belong to a calcgory of frequently ill people, namely whether she comes to hospital complaining for one and the same disease more o than 4 times a year, or more than 6 times a year complaining for different diseases?

48. Does the child s father belong to a category of frequently ill people, namely whether she comes to hospital complaining for one and the same disease more o than 4 times a year, or more than 6 times a year complaining for different diseases?

49. Does the child 's mother suffer from hypotension (the blood pressure is equal to 90160 and lower)?

"30. Does the child's father suffer from hypotension (the blood peessure is equal to 90160 and lower)?

"si. Did the child's mother use to smoke (including passive smoking) during pregnancy of 5 years before in?

52. Did the child's father use to smoke (including passive smoking) during mother's pregnancy or 5 years before it?

53. Does the child's mother suffer hypertonic discase (the blood pressure is equal to 14090 and higher)?

54. Does the child's father suffer hypertonic disease (the blood pressure is equal to $140 \% 90$ and higher)?

"35. Can the child's mother lifestyle be characterized as hypodynamic?

56. Can the child's father lifestyle be characterized as hypodynamic?

57. Was the child's mother often in stressful conditions at work or at home during pregnancy and 5 years before it?

58. Was the child's father often in stressful conditions at work or at home during mother's pregnancy and 5 years before in?

39. Did the child 's mother drink alcohol during pregnancy or 5 years before it?

60 . Did the child s father drink alcohol during pregnancy or 5 years before it?

61. Does the child s mother prefer fatty food?

62. Does the child's father prefer fatty food?

63. Does the child's mother prefer fried food?

64. Does the child 's father prefer fried food?

65. Does the chid's mother consume sugary non carbonated drinks or carbonated drinks, sugary juices, synups?

66. Does the chid's father consume sugary non carbonated drinks or carbonated drinks, sugary juices, synups?

67. Does the child s mother eat snacks in between food intakes?

68. Does the child s father eat snacks in between food intakes?

69. Does the child's mother use corticosteroids, immunosuppressants, anti-depressants, salicylates, acrosol medications to control asthma, homonal contraceptives or other medications?

70." Does the child's mother use corticosteroids, immunosuppressants, anti-depressants, salicylates, acrosol medications to control asthma, homonal contraceptives or other medications?

Fig. 1. Prognosis of the Risk Degree of Oral Pathology Formation in Macrosomic Newborns or Infants (Appendix to the Neonatal Case Record, Child's Record or Hospital Sheet).

The text of the questionnaire is given in an abbreviated form 
Declarations. The Ethical and bioethical committee of the Kharkiv National Medical University (Record No. 5 dated 10 May 2016) confirms that the techniques used in this study have beenapplied with the respect to human rights in accordancewith the current legislation in Ukraine, meet international ethicalrequirements and do not violate ethical norms inscience and standards for conducting biomedical research. The parents of each child gave written consent to participate in the study.

List of abbreviations. Confidence intervals (CI); Main Group (MG); Comparison Group (CG); Subgroup (SG); total parental factor (PF); percentage number of cases (PNC).

Conflict of interests

The authors declare that they have no competing interests.

\section{Results and discussion}

The results of comparing the total score of the dental anomalies risk factors in the $\mathrm{MG}$ and CG children (see Table 1) obtained from a big number of participants, confirmed the risk predominance in $\mathrm{MG}$ children and agreed with the results obtained earlier [17].

However, it should be noted that in $32(47.1 \%$ CI: 36.2-58.1\%) MG children and in $8(9.6 \% \mathrm{CI}$ : $5.1-16.6 \%)$ CG children at least one of the parents had a weight-height parameters at birth that corresponded to macrosomic. Therefore, these parents had significant dental problems which were proved by our previous studies [18]. Children of SG-I had macrosomic-at-birth parents in $18(48.6 \%$ of CI: $34.4-63.1 \%)$ cases, SG-II hadsuch parents in $6(42.9 \%$ CI: $23,0-64,9 \%)$ of cases, SG-III included 6 (60,0\% CI: 34.8-81.3\%), and SG-IV comprised 2 (28.6\% CI: 9.9-57.9\%) cases. This fact may be one of the explanations for the risk prevalence among the participants in SG-I, SG-II and SG-III over the CG. It should be noted that higher risks are also observed in children aged from 4 to 17 who were born with signs of intrauterine obesity in the background of acceleration (subgroup III) [19].

The test results analysis (Table 2 and Table 3) revealed that the points scored by the participants

Tabulated Scores of the Test Results of the CG, MG

Table 1 and Subgroups Partisipants, Depending on the Risk Degree

\begin{tabular}{|c|c|c|c|c|}
\hline $\begin{array}{l}\text { Groups and } \\
\text { Subgroups }\end{array}$ & Minimal Risk Degree & $\begin{array}{c}\text { Moderate Risk } \\
\text { Degree }\end{array}$ & $\begin{array}{c}\text { Significant Risk } \\
\text { Degree }\end{array}$ & $\begin{array}{c}\text { High Risk } \\
\text { Degree }\end{array}$ \\
\hline $\begin{array}{l}\text { Comparison } \\
\text { Group }\end{array}$ & $\begin{array}{c}7(8.4 \% \\
\mathrm{Cl}: 4.3-15.1 \%)\end{array}$ & $\begin{array}{c}42(50.6 \% \\
\mathrm{Cl}: 40.6-60.6 \%)\end{array}$ & $\begin{array}{c}32(38.6 \% \\
\mathrm{Cl}: 29.2-48.7 \%)\end{array}$ & $\begin{array}{c}2(2.4 \% \\
\text { Cl: } 0.8-6.5 \%)\end{array}$ \\
\hline $\begin{array}{l}\text { Main } \\
\text { Group }\end{array}$ & $\begin{array}{c}2(2.9 \% \\
\mathrm{Cl}: 0.9-7.9 \%)\end{array}$ & $\begin{array}{c}20(29.4 \% \\
\mathrm{Cl}: 20.2-40.1 \%)^{*}\end{array}$ & $\begin{array}{c}41(60.3 \% \\
\mathrm{Cl}: 49.2-70.6 \%)^{*}\end{array}$ & $\begin{array}{c}5(7.4 \% \\
\mathrm{Cl}: 3.3-14.4 \%)\end{array}$ \\
\hline Subgroup I & $\begin{array}{c}1(2.7 \% \\
\mathrm{Cl}: 0.7-9.5 \%)\end{array}$ & $\begin{array}{c}9(24.3 \% \\
\mathrm{Cl}: 13.8-38.2 \%)^{*}\end{array}$ & $\begin{array}{c}24(64.9 \% \\
\mathrm{Cl}: 50.2-77.5 \%)^{*}\end{array}$ & $\begin{array}{c}3(8.1 \% \\
\mathrm{Cl}: 3.0-18.2 \%)\end{array}$ \\
\hline Subgroup III & $\begin{array}{c}0(0.0 \% \\
\mathrm{Cl}: 0.3-30.8 \%)\end{array}$ & $\begin{array}{c}2(20.0 \% \\
\text { Cl: } 6.7-44.5 \%)\end{array}$ & $\begin{array}{c}6(60.0 \% \\
\mathrm{Cl}: 34.8-81.3 \%) \\
\end{array}$ & $\begin{array}{c}2(20.0 \% \\
\mathrm{Cl}: 6.7-44.5 \%)^{*}\end{array}$ \\
\hline Subgroup IV & $\begin{array}{c}1(14.3 \% \\
\mathrm{Cl}: 3.7-41.0 \%) \\
\end{array}$ & $\begin{array}{l}3(42.9 \% \\
\text { Cl: } 18.4-71.0 \%) \\
\end{array}$ & $\begin{array}{c}3(42.9 \% \\
\text { Cl: } 18.4-71.0 \%)\end{array}$ & $\begin{array}{c}0(0.0 \% \\
\text { Cl: } 0.4-41.0 \%)\end{array}$ \\
\hline
\end{tabular}

* - The difference from the CG is significant (within the 0.95 confidence interval).

Table 2

Tabulated Scores of the Test Results of CG, MG and Subgroups Participants Depending on the Scale of the Questionnaire

\begin{tabular}{|l|c|c|c|c|c|c|c|}
\hline $\begin{array}{c}\text { Groups } \\
\text { and Subgroups }\end{array}$ & Scale 1 & Scale 2 & Scale 3 & Scale 4 & Scale 5 & Scale 6 & Scale 7 \\
\hline $\begin{array}{l}\text { Comparison } \\
\text { Group }\end{array}$ & $2.65 \pm 0.35$ & $1.76 \pm 0.28$ & $3.80 \pm 0.49$ & $0.93 \pm 0.22$ & $1.35 \pm 0.23$ & $3.94 \pm 0.41$ & $4.59 \pm 0.48$ \\
\hline Main Group & $3.50 \pm 0.36^{*}$ & $2.38 \pm 0.37$ & $4.43 \pm 0.53$ & $1.51 \pm 0.32^{*}$ & $1.71 \pm 0.34$ & $3.93 \pm 0.43$ & $5.37 \pm 0.47$ \\
\hline Subgroup I & $\begin{array}{c}3.54 \\
(p=0.0026)^{*}\end{array}$ & $\begin{array}{c}2.59 \\
(p=0.0161)^{*}\end{array}$ & 4.57 & $\begin{array}{c}1.49 \\
(p=0.0054)^{*}\end{array}$ & 1.51 & 4.16 & 5.46 \\
\hline Subgroup II & $\begin{array}{c}2.50 \\
(p=0.0413)^{*} \\
(p=0.0227) \dagger \\
(p=0.0381)^{*}\end{array}$ & 4.71 & 1.43 & 1.79 & 3.93 & 5.07 \\
\hline Subgroup III & 3.70 & 2.10 & 4.50 & $\begin{array}{c}2.00 \\
(p=0.0389)^{*}\end{array}$ & $\begin{array}{c}2.30 \\
(p=0.0461)^{*}\end{array}$ & 3.60 & 5.90 \\
\hline Subgroup IV & 3.00 & 1.43 & 3.00 & 1.14 & 1.71 & 3.29 & 4.71 \\
\hline
\end{tabular}

* - The difference from the CG is significant (within the 0.95 confidence interval).

$\dagger-$ The difference from the SG -IV is significant (within the 0.95 confidence interval). 
Tabulated Scores of the Test Results of $C G, M G$

Table 3 and Subgroups Participants Depending On the Question

\begin{tabular}{|c|c|c|c|c|c|c|}
\hline $\begin{array}{l}\text { Question } \\
\quad \text { № }\end{array}$ & $\begin{array}{l}\text { Comparison } \\
\text { Group }\end{array}$ & $\begin{array}{l}\text { Main } \\
\text { Group }\end{array}$ & Subgroup I & Subgroup II & Subgroup III & Subgroup IV \\
\hline 1 & $6(7.2)$ & $8(11.8)$ & $3(8.1)$ & $1(7.1)$ & $2(20.0)$ & $2(28.6)$ \\
\hline 2 & $2(2.4)$ & $5(7.4)$ & $2(5.4)$ & $0(0.0)$ & $2(20.0)$ * & $1(14.3)$ \\
\hline 3 & $8(9.6)$ & $7(10.3)$ & $5(13.5)$ & $0(0.0)$ & $1(10.0)$ & $1(14.3)$ \\
\hline 4 & $6(7.2)$ & $4(5.9)$ & $0(0.0)$ & $3(21.4)$ & $1(10.0)$ & $0(0.0)$ \\
\hline 5 & $19(22.9)$ & $25(36.8)$ & $15(40.5)$ & $5(35.7)$ & $3(30.0)$ & $2(28.6)$ \\
\hline 6 & $15(18.1)$ & $27(39.7)^{*}$ & $14(37.8)$ & $7(50.0)^{*}$ & $4(40.0)$ & $2(28.6)$ \\
\hline 7 & $26(31.3)$ & $30(44.1)$ & $16(43.2)$ & $6(42.9)$ & $5(50.0)$ & $3(42.9)$ \\
\hline 8 & $37(44.6)$ & $33(48.5)$ & $19(51.4)$ & $6(42.9)$ & $5(50.0)$ & $3(42.9)$ \\
\hline 9 & $55(66.3)$ & $50(73.5)$ & $28(75.7)$ & $12(85.7)$ & $7(70.0)$ & $3(42.9)$ \\
\hline 10 & $46(55.4)$ & $49(72.1)$ & $29(78.4)$ & $9(64.3)$ & $7(70.0)$ & $4(57.1)$ \\
\hline 11 & $31(37.3)$ & $31(45.6)$ & $18(48.6)$ & $6(42.9)$ & $5(50.0)$ & $2(28.6)$ \\
\hline 12 & $19(22.9)$ & $17(25.0)$ & $12(32.4)$ & $3(21.4)$ & $2(20.0)$ & $1(14.3)$ \\
\hline 13 & $7(8.4)$ & $9(13.2)$ & $5(13.5)$ & $2(14.3)$ & $0(0.0)$ & $1(14.3)$ \\
\hline 14 & $10(12.0)$ & $9(13.2)$ & $5(13.5)$ & $1(7.1)$ & $2(20.0)$ & $1(14.3)$ \\
\hline 15 & $35(42.2)$ & $41(60.3)$ & $24(64.9)$ & $9(64.3)$ & $5(50.0)$ & $3(42.9)$ \\
\hline 16 & $21(25.3)$ & $19(27.9)$ & $9(24.3)$ & $6(42.9)$ & $4(40.0)$ & $0(0.0)$ \\
\hline 17 & $16(19.3)$ & $19(27.9)$ & $13(35.1)$ & $3(21.4)$ & $2(20.0)$ & $1(14.3)$ \\
\hline 18 & $1(1.2)$ & $8(11.8)^{*}$ & $7(18.9)^{*}$ & $1(7.1)$ & $0(0.0)$ & $0(0.0)$ \\
\hline 19 & $3(3.6)$ & $5(7.4)$ & $2(5.4)$ & $2(14.3)$ & $1(10.0)$ & $0(0.0)$ \\
\hline 20 & $3(3.6)$ & $4(5.9)$ & $1(2.7)$ & $2(14.3)$ & $0(0.0)$ & $1(14.3)$ \\
\hline 21 & $36(43.4)$ & $43(63.2)$ & $25(67.6)$ & $9(64.3)$ & $6(0.60)$ & $3(42.9)$ \\
\hline 22 & $46(55.4)$ & $44(64.7)$ & $25(67.6)$ & $11(78.6)$ & $6(0.60)$ & $2(28.6)$ \\
\hline 23 & $27(32.5)$ & $26(38.2)$ & $16(43.2)$ & $5(35.7)$ & $4(40.0)$ & $1(14.3)$ \\
\hline 24 & $28(33.7)$ & $30(44.1)$ & $18(48.6)$ & $7(50.0)$ & $4(40.0)$ & $1(14.3)$ \\
\hline 25 & $29(34.9)$ & $26(38.2)$ & $17(45.9)$ & $4(28.6)$ & $2(20.0)$ & $3(42.9)$ \\
\hline 26 & $34(41.0)$ & $28(41.2)$ & $17(45.9)$ & $6(42.9)$ & $2(20.0)$ & $3(42.9)$ \\
\hline 27 & $39(47.0)$ & $34(50.0)$ & $13(35.1)$ & 71.42857 & $8(0.80)$ & $3(42.9)$ \\
\hline 28 & $39(47.0)$ & $38(55.9)$ & $15(40.5)$ & $11(78.6)$ & $8(0.80)$ & $4(57.1)$ \\
\hline 29 & $24(29.0)$ & $18(26.5)$ & $15(40.5)$ & $1(7.1)$ & $2(20.0)$ & $0(0.0)$ \\
\hline 30 & $13(15.7)$ & $14(20.6)$ & $8(21.6)$ & $2(14.3)$ & $3(30.0)$ & $1(14.3)$ \\
\hline 31 & $8(9.6)$ & $12(17.6)$ & $5(13.5)$ & $4(28.6)$ & $3(30.0)$ & $0(0.0)$ \\
\hline 32 & $3(3.6)$ & $3(4.4)$ & $2(5.4)$ & $0(0.0)$ & $1(10.0)$ & $0(0.0)$ \\
\hline 33 & $2(2.4)$ & $4(5.9)$ & $2(5.4)$ & $0(0.0)$ & $2(20.0)^{*}$ & $0(0.0)$ \\
\hline 34 & $0(0.0)$ & $1(1.5)$ & $0(0.0)$ & $0(0.0)$ & $1(10.0)$ & $0(0.0)$ \\
\hline 35 & $2(2.4)$ & $7(10.3)$ & $3(8.1)$ & $2(14.3)$ & $1(10.0)$ & $1(14.3)$ \\
\hline 36 & $4(4.8)$ & $3(4.4)$ & $1(2.7)$ & $1(7.1)$ & $1(10.0)$ & $0(0.0)$ \\
\hline 37 & $4(4.8)$ & $11(16.2)^{*}$ & $7(18.9)$ & $1(7.1)$ & $2(20.0)$ & $1(14.3)$ \\
\hline 38 & $15(18.1)$ & $22(32.4)$ & $10(27.0)$ & $6(42.9)$ & $4(40.0)$ & $2(28.6)$ \\
\hline 39 & $30(36.1)$ & $28(41.2)$ & $18(48.6)$ & $4(28.6)$ & $4(40.0)$ & $2(28.6)$ \\
\hline 40 & $9(10.8)$ & $12(17.6)$ & $7(18.9)$ & $2(14.3)$ & $1(10.0)$ & $2(28.6)$ \\
\hline 41 & $14(16.9)$ & $14(20.6)$ & 7 (18.9) & $3(21.4)$ & $2(20.0)$ & $2(28.6)$ \\
\hline 42 & $9(10.8)$ & $13(19.1)$ & $7(18.9)$ & $1(7.1)$ & $4(40.0)^{*}$ & $1(14.3)$ \\
\hline 43 & $18(21.7)$ & $15(22.1)$ & $5(13.5)$ & $4(28.6)$ & $3(30.0)$ & $3(42.9)$ \\
\hline 44 & $6(7.2)$ & $11(16.2)$ & $4(10.8)$ & $4(28.6)$ & $2(20.0)$ & $1(14.3)$ \\
\hline 45 & $7(8.4)$ & $11(16.2)$ & $7(18.9)$ & $2(14.3)$ & $2(20.0)$ & $0(0.0)$ \\
\hline 46 & $5(6.0)$ & $8(11.8)$ & $5(13.5)$ & $1(7.1)$ & $2(20.0)$ & $0(0.0)$ \\
\hline 47 & $5(6.0)$ & $12(17.6)$ & $6(16.2)$ & $3(21.4)$ & $2(20.0)$ & $1(14.3)$ \\
\hline 48 & $6(7.2)$ & $5(7.4)$ & $2(5.4)$ & $2(14.3)$ & $1(10.0)$ & $0(0.0)$ \\
\hline 49 & $39(47.0)$ & $25(36.8)$ & $11(29.7)$ & $5(35.7)$ & $5(0.50)$ & $4(57.1)$ \\
\hline 50 & $3(3.6)$ & $2(2.9)$ & $2(5.4)$ & $0(0.0)$ & $0(0.0)$ & $0(0.0)$ \\
\hline 51 & $36(43.4)$ & $34(50.0)$ & $22(59.5)$ & $5(35.7)$ & $4(40.0)$ & $3(42.9)$ \\
\hline 52 & $54(65,1)$ & 61,76471 & $25(67,6)$ & $7(50,0)$ & $7(0,70)$ & $3(42,9)$ \\
\hline 53 & $11(13,3)$ & $12(17,6)$ & $6(16,2)$ & $2(14,3)$ & $2(20,0)$ & $2(28,6)$ \\
\hline 54 & $10(12,0)$ & $12(17,6)$ & $6(16,2)$ & $2(14,3)$ & $2(20,0)$ & $2(28,6)$ \\
\hline 55 & $15(18,1)$ & $9(13,2)$ & $5(13,5)$ & $3(21,4)$ & $1(10,0)$ & $0(0,0)$ \\
\hline 56 & $14(16,9)$ & $11(16,2)$ & $6(16,2)$ & $3(21,4)$ & $2(20)$ & $0(0,0)$ \\
\hline 57 & $37(44,6)$ & $37(54,4)$ & $18(48,6)$ & $10(71,4)$ & $5(50,0)$ & $4(57,1)$ \\
\hline 58 & $39(47,0)$ & $36(52,9)$ & $17(45,9)$ & $7(50,0)$ & $7(70,0)$ & $5(71,4)$ \\
\hline 59 & $52(62,7)$ & $34(50,0)$ & $23(62,2)$ & $8(57,1)$ & $1(10,0)$ * & $2(28,6)$ \\
\hline 60 & $59(71,1)$ & $41(60,3)$ & $26(70,3)$ & $8(57,1)$ & $5(50,0)$ & $2(28,6)$ * \\
\hline 61 & $29(34,9)$ & $28(41,2)$ & $14(37,8)$ & $5(35,7)$ & $7(70,0)$ & $2(28,6)$ \\
\hline 62 & $49(59,0)$ & $41(60,3)$ & $22(59,5)$ & $7(50,0)$ & $8(0,80)$ & $4(57,1)$ \\
\hline 63 & $51(61,4)$ & $47(69,1)$ & $27(73,0)$ & $10(71,4)$ & $7(70,0)$ & $3(42,9)$ \\
\hline 64 & $57(68,7)$ & $53(77,9)$ & $29(78,4)$ & $10(71,4)$ & $9(0,90)$ & $5(71,4)$ \\
\hline 65 & $59(71,1)$ & $55(80,9)$ & $32(86,5)$ & $11(78,6)$ & $7(70,0)$ & $5(71,4)$ \\
\hline 66 & $46(55,4)$ & $46(67,6)$ & $27(73,0)$ & $8(57,1)$ & $7(70,0)$ & $4(57,1)$ \\
\hline 67 & $42(50,6)$ & $42(61,8)$ & $22(59,5)$ & $10(71,4)$ & $7(70,0)$ & $3(42,9)$ \\
\hline 68 & $40(48,2)$ & $43(63,2)$ & $22(59,5)$ & $9(64,3)$ & $7(70,0)$ & $5(71,4)$ \\
\hline 69 & $6(7,2)$ & $5(7,4)$ & $3(8,1)$ & $1(7,1)$ & $0(0,0)$ & $1(14,3)$ \\
\hline 70 & $2(2,4)$ & $5(7,4)$ & $4(10,8)$ & $0(0,0)$ & $0(0,0)$ & $1(14,3)$ \\
\hline
\end{tabular}

* - The difference from the CG is significant (within the 0.95 confidence interval). 
on scale 1 were significantly different from the points scored by the CG participants (see Table 2). While analyzing the differences in subgroups, we found out that the "predominance" of complaints was achieved precisely because of the answers of those parents who were born macrosomic. In particular, the following responses were significantly different: they indicated that the newborn's father had a delay in the timing of the deciduous or permanent teeth eruption in 2 persons in the SG-III (20.0\% CI: $6.7-44.5 \%$ ) versus 2 people in the CG (2.4\% CI: $0.8-6.5 \%)$. The fact that the total number of carious, sealed and extracted teeth (DMF index) in the newborn's father exceeded 13, reported 27 MG people (39.7\% CI: $29,4-$ $50.8 \%)$ and 7 people in SG-II (50.0\% CI: 28.9 $71.1 \%)$ against 15 people in the CG $(18.1 \% \mathrm{CI}$ : 11.4-26.7\%).

There was no significant difference between the points scored by the $\mathrm{MG}$ and the $\mathrm{CG}$ participants in the questionnaire scale 2 (Table 2). Subgroup scores analysis showed that there were more complaints in the SG-I, SG-II and SG-III parents than in the $\mathrm{CG}$ parents. These differences were true for SG-1 and SG-II. In particular, there were significantly more cases where a newborn's father noted pain or crunch in the temporomandibular joint, changes in the movement of the mandible during opening or closing the mouth, namely 8 MG participants (11.8\% CI: $6.2-20,1 \%)$ and 7 SG-I participants
(18.9\% CI: 9.8-32.0\%) against CG (1.2\% CI: $0.3-4.3 \%)$.

The results questionnaires analysis in the part of the total parental factor (PF) influence on the risk of oral disorders formation in newborns (summarized results of scale 1 and scale 2), children (scale 1) and adults (scale 1) [18], are presented in Table 4.

According to our data for macrosomic newborns, the average score of PF is significantly higher than for normosomic newborns. But does PF really affect the risk of oral disorders formation in macrosomic newborns more than in normosomic? Note that one of the parents, regardless whether their newborn is macrosomic or normosomic, can also be normosomic-at birth, and macrosomic-at-birth. Data on each age category of a person participating in the survey on the total number of respondents, the number of macrosomic-at-birth parents and their relative number are presented in Table 5.

Since the state of the oral health (hence the number of complaints) in macrosomic- and normosomic-at-birth is different, and the relative number of macrocomic-at-birth parents in different categories of participants is also not the same, differences in the average score of the PF (Table 4) may occur due to this factor. Let us consider this question in details. We introduce the following notation: bn and bm - the average scores on the scale of the PF for cases where the father

Table 4

The Mean Score of the Total PF Influence on the Risk of Emergence and Formation of Oral Diseases in Macrosomic-At-Birth-Or Normosomic-At-Birth Participants of Different Age Categories

\begin{tabular}{|l|c|c|}
\hline $\begin{array}{c}\text { Age } \\
\text { Categories }\end{array}$ & $\begin{array}{c}\text { Mean Score of the Total PF } \\
\text { in Macrosomic-At-Birth Participants (MG), B1 }\end{array}$ & $\begin{array}{c}\text { Mean Score of the Total PF } \\
\text { in Normosomic-At-Birth Participants (CG), } B_{2}\end{array}$ \\
\hline \multirow{2}{*}{ Newborns } & $2.94 \pm 0.27$ & $2.20 \pm 0.23$ \\
& $\begin{array}{c}\text { (mean scale 1 score: } 3.50 \pm 0.36 \\
\text { mean scale 2 score: } 2.38 \pm 0.37 \text { ) }\end{array}$ & $\begin{array}{c}\text { (mean scale 1 score: } 2.65 \pm 0.35 \\
\text { mean scale 2 score: } 1.76 \pm 0.28)\end{array}$ \\
\hline Children & $3.49 \pm 0.44$ & $3.15 \pm 0.65$ \\
\hline Adults & $3.12 \pm 0.38$ & $2.80 \pm 0.36$ \\
\hline
\end{tabular}

Table 5

The Data on the Absolute and Relative Number of Macrosomic-At-Birth Parents Among the Survey Participants Depending on the Age Category and the Study Group

\begin{tabular}{|c|c|c|c|c|c|c|}
\hline \multirow[b]{2}{*}{$\begin{array}{c}\text { Age } \\
\text { Categories }\end{array}$} & \multicolumn{3}{|c|}{ Macrosomic-at-birth person (MG) } & \multicolumn{3}{|c|}{ Normosomic-at-birth person (CG) } \\
\hline & $\begin{array}{l}\text { Total number } \\
\text { of respondents, } \\
\Sigma_{1}\end{array}$ & $\begin{array}{c}\text { Number } \\
\text { of macrosomic- } \\
\text { at-birth pearents, } \\
\text { m }_{1}\end{array}$ & $\begin{array}{c}\text { Relative } \\
\text { number } \\
\text { of macrosomie } \\
\text { at-birth } \\
\text { pearents, } \\
\mathrm{m}_{1} / \Sigma_{1}\end{array}$ & $\begin{array}{l}\text { Total number } \\
\text { of respondents } \\
\qquad \Sigma_{2}\end{array}$ & $\begin{array}{c}\text { Number of } \\
\text { macrosomic-at- } \\
\text { birth pearents, } \\
\mathrm{m}_{2}\end{array}$ & $\begin{array}{c}\text { Relative } \\
\text { number of } \\
\text { macrosomic-at- } \\
\text { birth pearents } \\
\mathrm{m}_{2} / \Sigma_{2}\end{array}$ \\
\hline Adults & 114 & 33 & 0.290 & 127 & 10 & 0.079 \\
\hline
\end{tabular}


and mother of the participant are the normosomic and when one of them is macrosomic-at-birth respectively; $\mathrm{n}$ and $\mathrm{m}$ is the number of cases where the father and mother of the participant are the normosomic and when one of them was born with macrosomia, respectively. Then for the average score of the PF you can write:

$$
B=\frac{b_{n} n+b_{m} m}{n+m}=\frac{b_{n} n+b_{m} m}{\Sigma},
$$

where $\Sigma=\mathrm{n}+\mathrm{m}$ is the total number of respondents. Let the indexes 1 and 2 refer to the cases of the participant who was macrosomicat-birth and the normosomic-at-birth person, respectively. Then the ratio of the average score of the PF for these cases has the form:

$$
\frac{B_{1}}{B_{2}}=\frac{1+(k-1) \frac{m_{1}}{\Sigma_{1}}}{1+(k-1) \frac{m_{2}}{\Sigma_{2}}}
$$

Here $m / \Sigma$ is the relative number of cases where any of the parents was at birth macrosomic; $k=b_{m} /\left(b_{n}\right)$ is a coefficient that shows how much more average dental complaints are in the macrosomic than in the normosomic-at-birth partisipants. To begin with, we define this coefficient, for example, for the category "children"[19]:

$$
k=1+\frac{1-\frac{B_{1}}{B_{2}}}{\frac{m_{2}}{\Sigma_{2}} \frac{B_{1}}{B_{2}}-\frac{m_{1}}{\Sigma_{1}}} \approx 1+\frac{1-\frac{3.49}{3.15}}{0.244 \frac{3.49}{3.15}-0.402} \approx 1.82 .
$$

Thus, the macrosomic-at-birth parents complain almost 2 times more than the normosomic-at-birth parents. Now we calculate by the formula

$$
B_{1}=B_{2} \frac{1+(k-1) \frac{m_{1}}{\Sigma_{1}}}{1+(k-1) \frac{m_{2}}{\Sigma_{2}}}
$$

The average score for the macrosomic-atbirth person in all age categories is compared with the data given in Table 4. The results of calculations are given in Table 6. We can see that the estimated values are quite close to those obtained from the questionnaires [18, 19], which indicates the adequacy of the hypothesis about the reason for the variability of the average score of the PF, at least within the same age category.

Consequently, the score for scales 1 and 2 should be adjusted taking into account the weightheight parameters of the parents at birth.

The survey showed that according to scale 3, the MG participants, together and in the subgroups, had no significant difference in the number of points compared to the CG (Table 2).

Scale 4 includes a set of questions aimed at identifying the factors of the child's family-genetic predisposition to the fetal macrosomia. A significant difference was found between the $\mathrm{CG}$ and MG (Table 2).

Comparative analysis in the subgroups revealed a significantly higher number of points in individuals of SG-I and SG-III. In these subgroups we found a significantly higher percentage of parents born macrosomic.

Parents of SG-III children have the highest percentage number of cases (PNC) of big anthropometric parametres among all participants in the study (Table 3), which has also been confirmed in other age groups [19], as well as PNC of diabetes. In particular, the PNC of diabetes mellitus was significantly higher in newborn's mothers (Table 3) of SG-III and comprised 2 persons (20.0\% CI: $6.7-44.5 \%$ ) versus 2 persons in the CG $2(2.4 \% \mathrm{CI}: 0.8-$ $6.5 \%$ ). This subgroup is also the "leader" among participants in other age categories (children, adults) [19].

The overall assessment of the true difference between the MG and $\mathrm{CG}$ on the scale 5 was not detected which can be seen in Table 2. But the PNC of the parents concomitant pathology was significantly higher in SG-III than the same factor in CG. In particular, PNC of atopic dermatitis, bronchial asthma, allergic rhinitis or other allergic manifestations in the newborn's father was significantly higher in SG-III - 4 persons $(40.0 \%$ CI: $18.7-65.2 \%$ ) versus 9 persons in the CG (10.8\% CI: $5.9-18.1 \%)$. It is appropriate to say that every father, who indicated the presence of

Comparison of Actual and Estimated Average Parental Factor Scores

Table 6 in Different Age Categories and Groups of Participants Under Study

\begin{tabular}{|l|c|c|}
\hline $\begin{array}{c}\text { Age } \\
\text { Categories }\end{array}$ & $\begin{array}{c}\text { Average score of the PF } \\
\text { for the macrosomic-person (actual), } B_{1}\end{array}$ & $\begin{array}{c}\text { Average score of the PF } \\
\text { for the macrosomic-person (calculated), } B_{1}\end{array}$ \\
\hline Newborns & $2.94 \pm 0,27$ & 2.83 \\
\hline Children & $3.49 \pm 0.44$ & 3.49 \\
\hline Adults & $3.12 \pm 0.38$ & 3.26 \\
\hline
\end{tabular}


allergic diseases, was found to be born macrosomic. The facts we have discovered are confirmed by other scholars. It is known that allergic reactions occur much more often if a person before the age of 2 was obese [20]. The interrelation of obesity and asthma is also confirmed by the authors of the study [21].

Significant difference between the MG and CG in scale 6 also was not detected (Table 2). However, the PNC of alcoholic beverages consumption by mothers during pregnancy or during 5 years before pregnancy in SG-III was significantly lower than in the CG: 1 person (10.0\% CI: $2.5-30.8 \%)$ against 52 persons (62.7\% CI: $52.6-71.9 \%)$, respectively. PNC of alcoholic beverages consumption by fathers during 5 years before pregnancyof a newborn's mother in SG-IV was significantly lower than in the CG: 2 persons (28.6\% CI: 9.9-57.9\%) versus 60 persons (72.3\% CI: 62.7-80.5\%), respectively. There was no significant difference, or tendencies in one or another direction, between subgroups and CG in all other questions related to this scale.

There was no significant difference between the MG and subgroups and CG (Table 2, Table 3) in the scale 7.

Discussion. Until recently, research papers concerned with the study of the features of dental disorders formation in individuals born with macrosomia have been extremely few. Now the situation is starting to change and many research papers that confirm the high intensity and prevalence of caries, as well as other dental disorders, in macrosomic at birth persons have been published. [22, 23].

As mentioned above, there is genetic predisposition for certain dental disorders [24, 25]. But this tendency is manifested in both the group of macrosomic newborns and the group of normosomic newborns.

Taking into account the drastic variety among macrosomic newborns, in particular, due to their different height-weight index at birth [26], the dental state specific to each subgroup is subsequently formed $[8,9,15,19]$. We hoped to reveal some differences in the parents of macrosomic children in the different subgroups, namely: eating habits, bad habits, features of dental status, etc. However, taking into account that some parents were also born macrosomic, it has turned out that the survey of parents of macrosomic children in the different subgroups shows no certain difference in the results. That is, poor oral health that occur in ontogeny in macrosomic at birth persons is most likely more closely related to the same metabolic patterns that summed into the fetal macrosomia $[27,28]$ but not to a set of factors grouped in our questionnaire (parents' pathology of hard tooth and periodontal tissues, malloclusions, state of oral hygiene, comorbidity, their social habits, locomotor activity before pregnancy and during it, or the nature of nutrition and medical therapy).

After a detailed analysis of the subgroups and comparison group of these data with the data of the questionnaire of older age groups, it was concluded that the effect of the total paternal factor on the formation of oral disorders in individuals with macrosomia at birth, can be different from the effect of this factor in normosomicat birth persons, but this difference is related to the same phenomenon that we are studying - the fetal macrosomia, but the paternal one.

Perhaps, one of the factors, which influence the onset of dental disorders in ontogeny, is the reduced bone mineral density in macrosomic newborns, which is associated with the features of macrosomic fetus formation and intrauterine metabolic and immune shifts in the macrosomic fetus [29-31].

\section{Conclusions}

1. The hygienic state of the oral cavity of parents, the presence of concomitant pathologyof parents, bad habits and the degree of locomotor activity before pregnancy, and during pregnancy, peculiarities of nutrition and medical therapy of parents influence practically identically on the formation of oral disorders in the first year of life in children born macrosomic, regardless of the weight-height index at birth, or in children born normomic. Reliable differences between groups and subgroups were not detected.

2. According to the past history data and complaints of parents, the highest risk of the oral pathology formation have children whose parents were born macrosomic.

3. Factors influencing the formation of fetal macrosomia in the intrauterine period, in addition to heredity, defects in oral hygiene or concomitant pathology, ground the patterns of "disturbed" oral health. A person born macrosomic, on the average, has twice as many complaints about oral health compared to a person born normosomic.

Acknowledgements. The author would like to thank the parents who took part in the study and the medical staff of Kharkiv Municipal Perinatal Center (Ukraine) for their assistance and time. 


\section{References}

1. Morikawa M., Cho K., Yamada T., Yamada T., Sato S,. Minakami H. (2013). Fetal macrosomia in Japanese women. J Obstet Gynaecol Res., 39(5), 960-5. doi: 10.1111/j.1447-0756.2012.02059.x

2. Godfrey, K. M., Inskip, H. M., Hanson, M. A. (2011). The long term effects of prenatal development on growth and metabolism. Seminars in Reproductive Medicine, 29(3), 257-265. http://doi.org/10.1055/ s-0031-1275518.

3. Huraseva, A. B. (2010). Reproduktivnoe zdorove zhenschin, rodivshihsya s polyarnyimi znacheniyami massyi tela [Reproductive health of women born with polar body weight]. Mizhnarodnii endokrynolohichnii zhurnal, 8, 106-115 [in Russian].

4. Pan X. F., Tang L., Lee A. H., Binns C., Yang C. X., Xu Z. P., Zhang J. L., Yang Y., Wang H., Sun $X$. (2019). Association between fetal macrosomia and risk of obesity in children under 3 years in Western China: a cohort study. World J Pediatr, 15(2), 153-160. doi: 10.1007/s12519-018-0218-7.

5. Hermann, G.M., Dallas, L.M., Haskell, S.E., Roghair, R.D. (2010). Neonatal macrosomia is an independent risk factor for adult metabolic syndrome. Neonatology, 98 (3), 238-244.

6. Yokomichi, H., Tanaka, T., Suzuki, K., Akiyama, T., Okinawa Child Health Study Group, \& Yamagata, Z. (2015). Macrosomic Neonates Carry Increased Risk of Dental Caries in Early Childhood: Findings from a Cohort Study, the Okinawa Child Health Study, Japan. PLoS ONE, 10 (7), e0133872. http://doi.org/10.1371/journal.pone.0133872.

7. Julihn, A., Molund, U., Drevs?ter, E., Modaer, T.(2014). High birth weight is a risk factor of dental caries increment during adolescence in Sweden. Dentistry Journal, 2(3), 118-33. http://doi.org/10.3390/ dj2040118.

8. Garmash OV. (2018). Features of the dental state of children with fetal macrosomia in the period of the temporary dentition. Visnyk problem biolohii i medytsyny, 4 (1/146), 246-253 [in Ukrainian].

9. Garmash O., Ryabokon E. N. (2017). The effect of fetal macrosomia on the neonate and infant dental health. International Journal of Clinical Dentistry, 10 (3), 199-210.

10. A. Alm, L. K. Wendt, G. Koch, D. Birkhed, M. Nilsson. (2012). Caries in adolescence - influence from early childhood Community Dent Oral Epidemiol. 40(2), 125 33. doi: 10.1111/j.1600-0528.2011.00647.x.

11. Moreno L. M., Uribe S. F. Miller. (2015). Genetics of the dentofacial variation in human malocclusion Orthod Craniofac Res. 18 (01): 91-99. doi: 10.1111/ocr.12083.

12. Ntani G., Day P. F., Baird J., Godfrey K. M, Robinson S. M., Cooper C., Inskip H. M., and the Southampton Women's Survey Study Group. (2015). Maternal and early life factors of tooth emergence patterns and number of teeth at one and two years of age J Dev Orig Health Dis., 6(4): 299-307. doi: $10.1017 / \mathrm{S} 2040174415001130$

13. Garmash O.V., Ryabokon E.N., Korobchanskyi V.O Prohnozuvannia ryzyku porushen zuboshchelepnoi systemy v novonarodzhenykh ta ditei hrudnoho viku iz makrosomiieiu (dodatok do karty rozvytku novonarodzhenoho, istorii rozvytku dytyny abo medychnoi karty statsionarnoho khvoroho) [Prediction of risk of dental system violations formation in newborns and infants with macrosomia (Appendix to the Neonatal Case Record, Child's Record or Hospital Sheet)]. Cvidotstvo pro reiestratsiiu avtorskoho prava na tvir № 64101 vid 15.02.2016 [in Ukrainian].

14. Grischenko VI., Yakovtsova AF. Krupnyiy plod (kliniko-morfologicheskoe issledovanie) [Large fetus (clinical and morphological study)]. In: V. I. Grischenko, A. F. Yakovtsova. Kiev: Zdorovya; 1991, p. 183 [in Russian].

15. Garmash O.V. (2018) Dentists view on fetal macrosomia Svit Medytsyny ta Biolohii", № 4 (66), 040-046. doi:10.26724/2079-8334-2018-4-66-40-46.

16. Gerasimov A.N. (2007). Medical statistics. Moscow: Medical News Agency;: 480 [in Russian].

17. Garmash O.V. (2016). Prognozirovaniye riska formirovaniya narusheniy zubochelyustnoy sistemy u novorozhdennykh i detey grudnogo vozrasta s makrosomiyey (klinicheskaya aprobatsiya oprosnika). [Prediction of formation of dental system violations in newborns and infants with macrosomia (clinical tasting of the questionnaire)] Meditsinskiy zhurnal severnogo Kazakhstana. 3 (51). 52-56 [in Russian].

18. Garmash O.V. Vyiavlennia faktoriv ryzyku zakhvoriuvan tkanyn parodontu i tverdykh tkanyn zubiv u patsiientiv, narodzhenykh z makrosomiieiu (klinichna aprobatsiia opytuvalnyka) 2015. [Risk factors ror periodontal and hard tooth tissues diseases in patients born with macrosomia identifying (clinical tasting of the questionnaire)] Visnyk problem biolohii i medytsyny, 4 (2/125), 348-352 [in Ukrainian]. 
19. Garmash O. V. (2019). Zalezhnist ryzyku vynyknennia stomatolohichnykh porushen u ditei ta pidlitkiv, narodzhenykh iz makrosomiieiu, vid indeksu masy tila pry narodzhenni [Dependence of a risk of oral abnormalities in children and adolescents born macrosomic on their height-weight index at birth]. Visnyk problem biolohii i medytsyny, 2 (1/150). [in Ukrainian].

20. Silverberg J. I., Kleiman E., Lev-Tov H, Silverberg N. B., Durkin H. G., Joks R., Smith-Norowitz T.A. (2011). Association between obesity and atopic dermatitis in childhood: A case-control study. J Allergy Clin Immunol., 127(5), 1180-6.e1. doi: 10.1016/j.jaci.2011.01.063.

21. Baruwa P., Sarmah K.R. (2013). Obesity and asthma. Lung India, 30 (1), 38-46.

22. Yamagata Z., Yokomichi H., Suzuki K., Tanaka T. (2015) Macrosomia is One of Risk Factors for Dental Caries in 3-year-old Infants in Japan.International Journal of Epidemiology, 44 (1), i77-i78.

23. Huraseva, A. B. (2014). Adaptatsiya novorozhdennykh i ikh razvitiye v pervyy god zhizni $v$ zavisimosti ot massy tela pri rozhdenii. [Adaptation of newborns and their development in the first year of life depending on body mass at the birth] Nauchnyye vedomosti Belgorodskogo gosudarstvennogo universiteta. Meditsina. Farmatsiya. 4/175 (25), 102-105. [in Russian].

24. Germec-Cakan D., Ulkur F., Taner T. (2012). The genetic basis off acial skeletal characteristics and its relation with orthodontics. Eur J Dent., 6(3), 340-345.

25. Patel Z, Ifzah, Sheikh H. (2016) Genetics in orthodontics- a review. EJPMR, 3(7): 539-545.

26. Yakovtsova A.F., Sorokina I.V., Aleshchenko I.E. (2004) Imunnaya sistema ploda cheloveka pri krupnoplodii i ZVRP [Immune system of the human fetus in large and IUGR fetuses]. Kharkov: BSF "Antiqua"; 218. [in Russian].

27. Donma M.M. Macrosomia, top of the iceberg: the charm of underlying factors. (2011). PediatrInt., 53 (1),78-84. doi: 10.1111/j.1442-200X.2010.03198.x.

28. Gu S, An X, Fang L, Zhang X, Zhang C, Wang J [et al.] (2012). Risk factors and long-term health consequences of macrosomia: a prospective study in Jiangsu Province. J Biomed Res., 26 (4), 235-240, doi: 10.7555/JBR.26.20120037.

29. Littner Y, Mandel D., Mimouni F.B., Dollberg S. (2004) Decreased bone ultrasound velocity in large-for-gestational-age infants. J Perinatol., 24(1), 21-3.

30. Schushan-Eisen I., Cohen M., Leibovitch L., Maayan-Metzger A., Strauss T. (2015). Bone Density Among Infants of Gestational Diabetic Mothers and Macrosomic Neonates. Maternal and Child Health Journal, 19 (3), 578-582.

31. Sorokina I.V. (2013). Krupnyj plod: mifyi i real'nost' [A large fetus: myths and realities]. Rossijskij vestnik akushera-ginekologa, 13(4), 86-88. [in Russian].].

Received: 12-Apr-2019

Accepted: 09-Sep-2019 